\title{
A study of comparison between ionized calcium and albumin corrected calcium in patients with chronic kidney disease
}

\author{
C. Suvarna Devi ${ }^{1}$, R. Ramya ${ }^{2}$, H. R. Suma ${ }^{3}$, J. N. Naidu ${ }^{4}$, M. Prasad Naidu ${ }^{5, *}$ \\ ${ }^{1}$ Assistant Professor, ${ }^{2}$ Fellow in Cytogenetics, ${ }^{3}$ Associate Consultant, ${ }^{4}$ Professor \& HOD, ${ }^{5}$ Tutor,,${ }^{13,4,5}$ Dept. of Biochemistry, \\ ${ }_{1,4,5}$ Narayana Medical College and Hospital, Nellore, Andhra Pradesh, ${ }^{2}$ Centre for DNA Fingerprinting and Diagnostics, \\ Hyderabad, Telangana, ${ }^{3}$ Sakra World Hospital, Bangalore, Karnataka, India
}

Received: $30^{\text {th }}$ October, 2017

*Corresponding Author:

Email: m.prasadnaidu@ymail.com

Accepted: $24^{\text {th }}$ February, 2018

\begin{abstract}
Chronic kidney disease (CKD) is a global health issue rising in alarming rate. Diseases of mineral and bone metabolism are more common in chronic kidney disease. This study was aimed to evaluate comparison between ionized calcium and albumin corrected calcium in Subjects with CKD with dialysis treatment, to assess their calcium levels. Subjects with CKD on dialysis treatment, who presented to the Department of Medicine, PESIMSR, Kuppam were included into the study. Sample $(\mathrm{n}=40)$ was collected from all patients from AV fistula. This was used to analyze total calcium, serum albumin, $\mathrm{pH}$ and also ionized calcium values. Albumin corrected calcium is calculated using equation. The preliminary data analyses reporting a significant variation among ionized calcium and total calcium besides albumin corrected calcium in patients with CKD $(p<0.001)$. The factors that influence the ionized calcium levels are being currently determined.There is a significant variation among ionized calcium and total as well as albumin corrected calcium in subjects with CKD $(P<0.001)$. These results need further analyses to identify factors that influence ionized calcium levels. This will help us to know the importance of ionized calcium in estimating calcium levels in CKD subjects.
\end{abstract}

Keywords: Albumin, Total Calcium, Ionized Calcium, Dialysis, Chronic Kidney Disease.

\section{Introduction}

Chronic kidney disease (CKD) is emanate to be an foremost disease worldwide with increasing present incidence of diabetes and hypertension. ${ }^{1}$ In India about 1 billion population having increased incidence of CKD are more prone to develop both health care and economy problems in future. ${ }^{2} \mathrm{CKD}$ is most commonly associated with abnormalities mainly in mineral and bone metabolism. Frequently assessment of bone and mineral disorders compulsory in CKD subjects. ${ }^{3}$

Estimated total calcium in serum be found in $13 \%$ bound to organic and inorganic anions, around $40 \%$ albumin bound and remaining present as biologically active ionized calcium(47\%), ${ }^{4,5}$ The National kidney foundation kidney disease outcomes quality initiative (KDOQI) clinical practice guidelines recommended the estimation of serum total calcium, corrected for albumin to evaluate the calcium levels in CKD subjects. ${ }^{6}$

Kidney disease is an improving worldwide outcome (KDIGO) guidelines have acknowledged that assessment of ionized calcium is the best method for estimating calcium levels in CKD subjects. ${ }^{7}$ Depending on the above rules and regulationssome studies reported that there is a fair accruement among these parameters in CKD subjects. Although some other studies were reported that non-corrected and albumin corrected that total calcium levels weak predictors of calcium levels in CKD subjects. ${ }^{8}$

Hence the present study compare the values of Ionized calcium along with Total and Albumin corrected calcium levels with CKD subjects.

\section{Materials and Methods}

This study includedpatients with CKD, on maintenance dialysis, who presented to the Department of Medicine, PESIMSR, Kuppam. Adults aged 20-70 years of both genders, well established cases of CKD on maintenance dialysis were included. We excluded acute renal failure patients, those who declined to give consent for the study and Patients with renal transplant. An informed consent was obtained from all subjects recruited into the study. Sample size was decided to carry out a pilot study on 40 patients with CKD. Two Pre dialysis arterialized venous blood sample $(n=40)$ were collected from all patients. Subjects Serum was aseptically sampled for immediate estimation of Ionized calcium.The sample additionally used for estimate; Total calcium, Serum albumin and $\mathrm{pH}$.

Total calcium analysed by Automated analyzer (VITROS 250) based on reflectance photometry through Arsenazo III method. Serum albumin estimated by Automated analyzer (VITROS 250) based on reflectance photometry through BCG Dye binding processes. Ionized calcium and $\mathrm{pH}$ estimated by Automated analyzer (ESCHWEILER) depend on Potentiometry with ISE. Albumin corrected calcium was analyzed with the below equation:

[Albumin corrected calcium $=$ Total calcium $(\mathrm{mg} / \mathrm{dl})$ $+0.0704 \times(34$-Albumin $(\mathrm{g} / \mathrm{l})]$.

Ionized calcium was taken as the basis for differentiating categories of overestimation and underestimation of agreement values. Patients were also categorized into normocalcaemia, hypocalcaemia and 
hypercalcaemia depend on Total calcium, Albumin corrected calcium and Ionized calcium estimations.

\section{Statistical Analysis}

Statistical data calculated by using SPSS software version 16. One-sample Kolmogorov-Smirnov methodto check normal distribution of values. Total, Albumin corrected and Ionized calcium values were converted to $\mathrm{z}$-scores for comparison using following this formula: $z$ score $=$ (measured $\mathrm{Ca}-$ mean $\mathrm{Ca}) / \mathrm{SD}$. One way analysis of variance (ANOVA)- used to compare $\mathrm{z}$ scores. Post- hoc tests used for inter-group comparison of $p$ value of less than 0.05 was considered statistically significant. The comparison between categories based on Ionized calcium was done by subtracting $\mathrm{z}$-score values of Ionized calcium from $\mathrm{z}$-score values of Total calcium. If the values are negative considered as underestimation, if the values are positive considered as overestimation.

\section{Results}

A total of 40 subjects with stages 3 to 5 CKD were included in this study. By using serum total calcium as the reference, 23 subjects has normal levels and 17 has hypocalcaemia. By using serum albumin corrected calcium as the reference, 25 subjects has normal levels and 15 has hypocalcaemia. By using ionised calcium as the reference, 36 subjects has normal levels, 1 has hypocalcemia and 3 hashypercalcemia (Table 1).

Table 1: Frequency distribution

\begin{tabular}{|l|c|c|c|}
\hline Parameters & $\begin{array}{c}\text { Normocalcaemic } \\
\text { patients }\end{array}$ & $\begin{array}{c}\text { Hypocalcaemic } \\
\text { patients }\end{array}$ & $\begin{array}{c}\text { Hypercalcaemic } \\
\text { patients }\end{array}$ \\
\hline Total calcium & 23 & 17 & 0 \\
\hline $\begin{array}{l}\text { Albumin corrected } \\
\text { calcium }\end{array}$ & 25 & 15 & 0 \\
\hline Ionized calcium & 36 & 1 & 3 \\
\hline
\end{tabular}

Analysis of ionized calcium was moresignificant ( $p$ Value<0.001) when variation with total calcium and albumin corrected calcium for categarizing the variables into normocalcaemia as well as hypocalcaemia (Table 1 and 2).

Table 2: A comparison of total calcium, albumin-corrected calcium, and ionized calcium concentration in normocalcemic and hypocalcemic patients were expressed as $z$ scores (means \pm SD)

\begin{tabular}{|l|c|c|c|c|}
\hline \multicolumn{1}{|c|}{ Subjects } & $\begin{array}{c}\text { Total calcium (mg/dl) } \\
\text { Mean } \pm \text { SD }\end{array}$ & $\begin{array}{c}\text { Albumin corrected } \\
\text { calcium }(\mathbf{m g} / \mathbf{d l}) \\
\text { Mean } \pm \text { SD }\end{array}$ & $\begin{array}{c}\text { Ionized calcium } \\
\text { (mg/dl) Mean } \pm \\
\text { SD }\end{array}$ & $p$ Value \\
\hline Normocalcaemia & $0.6125 \pm 0.8569$ & $0.5862 \pm 0.7426$ & $-0.0445 \pm 0.6934$ & $<0.001^{*}$ \\
\hline Hypocalcaemia & $-0.8286 \pm 0.3983$ & $-0.9748 \pm 0.7757$ & $2.7824 \pm 0.4684$ & $<0.001^{*}$ \\
\hline
\end{tabular}

Table 3: Inter group comparison of the three variables total calcium, ionized calcium and albumin corrected calcium in normocalcemic subjects by post hoc test

\begin{tabular}{|c|c|c|c|}
\hline Subjects & $\begin{array}{c}\text { Total calcium } \\
\text { Vs } \\
\text { Ionized calcium }\end{array}$ & $\begin{array}{c}\text { Total calcium } \\
\text { Vs } \\
\text { Albumin corrected } \\
\text { calcium }\end{array}$ & $\begin{array}{c}\text { Albumin corrected calcium } \\
\text { Vs } \\
\text { Ionized calcium }\end{array}$ \\
\hline Normocalcaemia & $0.005^{*}$ & 1.00 & $0.006^{* *}$ \\
\hline
\end{tabular}

* Significant variation between Total calcium and Ionized calcium.

** Significant variation between Albumin corrected calcium and Ionized calcium.

Table 3 showed that in normocalcaemic subjects by using ionized calcium, 5 subjects (14\%) fell withinthe reference range for the laboratory. 14 patients (38\%) had hypercalcaemia. also $14 \%$ of patients the total and ionised calcium levels were in agrrement with reference levels and in $38 \%$ of case the total and ionised calcium levels were overestimated.

Table 4: Comparison between Total calcium and Ionized calcium in normocalcaemia

\begin{tabular}{|l|c|c|}
\hline $\begin{array}{l}\text { Variation OF Z-Scores of } \\
\text { total \& ionized calcium }\end{array}$ & $\begin{array}{c}\text { No of } \\
\text { patients }\end{array}$ & $\begin{array}{c}\text { Percentage } \\
(\%)\end{array}$ \\
\hline Inagreement & 5 & 14 \\
\hline Overestimation & 14 & 38 \\
\hline
\end{tabular}


Fig. 1 show snormocalcemia with use of albumin-corrected and total calcium dispite low ionized calcium values.

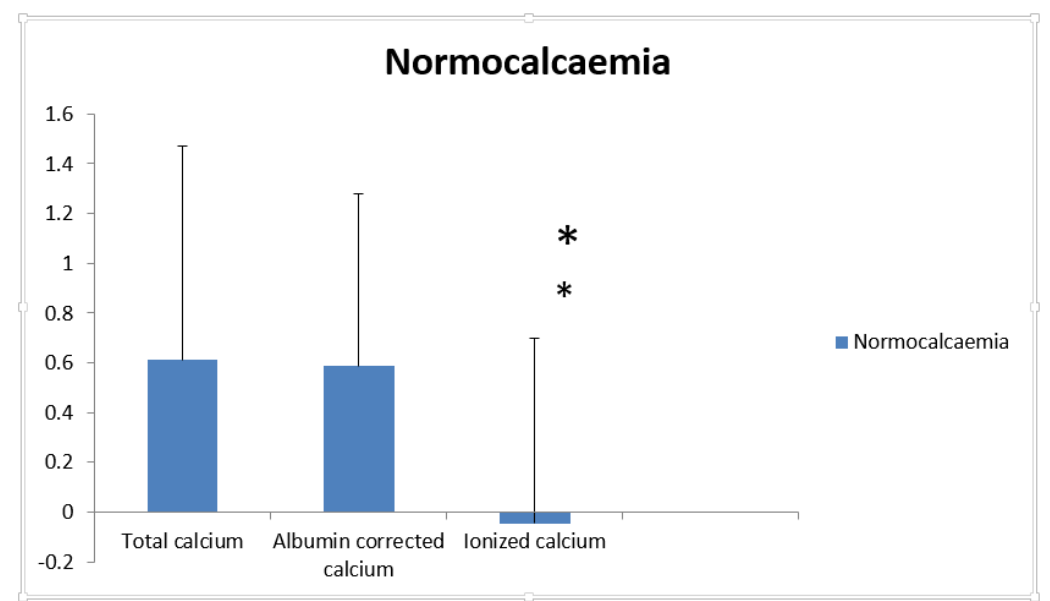

* Suggestive significance between Total calcium and Ionized calcium.

${ }^{* * *}$ Suggestive significance between Ionized calcium and Albumin corrected calcium.

Fig. 1: z-score values of normocalcaemia between three study variables

Fig. 2 shows hypocalcemia with use of albumin-corrected and total calcium dispite normal ionized calcium values.

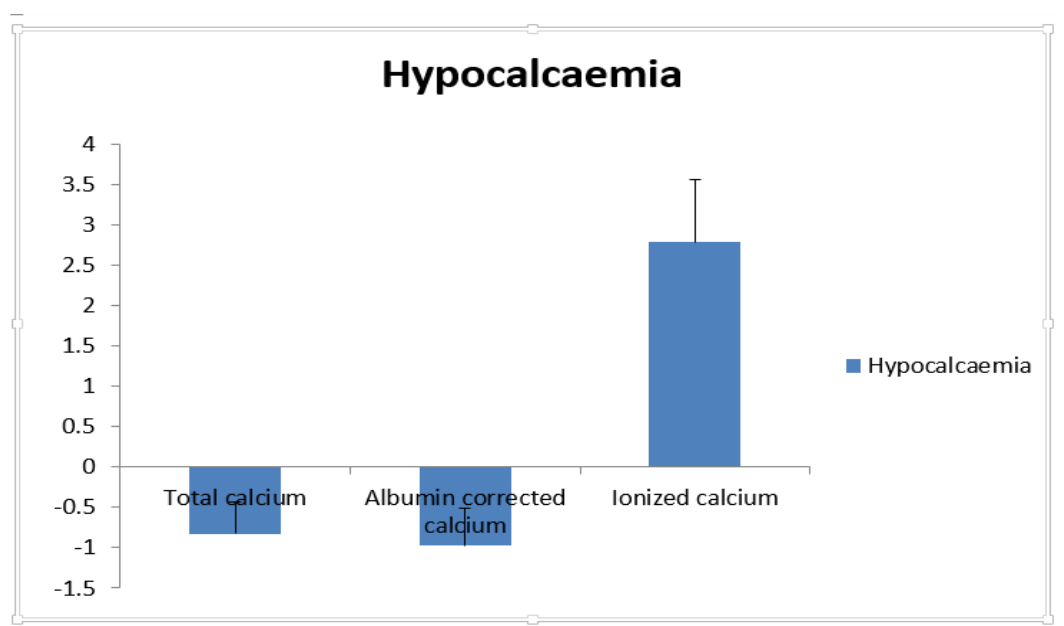

Fig. 2: z-score values of hypocalcaemia between three study variables

\section{Discussion}

The distribution of low, normal and high calcium levels varied depending to the estimators used. Clase $\mathrm{CM}$ et al shows approximately $10 \%$ of the patients were misclassified when used Total calcium or albumincorrected calcium was used. ${ }^{9}$ Z-scores were used to considered at the accruement among Total calcium and Ionized calcium values. Ammirati $\mathrm{AL}$ et al results correlated with our study it was found that among normo-calcaemic patients, $14 \%$ of the values were in agreement while ionized calcium was overestimated in $38 \%$ and underestimated in $47 \% .^{10}$ Previous studies have indicated that $\mathrm{pH}$ is an independent predictor of Ionized calcium. Gucalp R, et al shows there was study $\mathrm{pH}$ did not have any effect. This could be because of small sample size of the study. ${ }^{11}$ Linear regression analysis also showed that serum albumin levels have an influence on Ionized calcium levels $(r=0.388)$. Hecking $\mathrm{M}$, et al reported be that as it may a univariate and multivariate regression analysis is required to see if serum albumin levels overestimate or underestimate Ionized calcium. Ionized calcium values may be influenced by other factors such as calcium supplementation, GFR, serum phosphorus levels. ${ }^{12}$ Data obtained on these parameters were inadequate to perform multivariate logistic regression to look at their effect.Hence a bigger sample size and better data collection may throw light on factors that determine over estimation and underestimation of ionized calcium.

\section{Conclusion}

Albumin-corrected calcium does not perform better than total calcium in predicting the ionized calcium 
status. This study suggests that direct measure of ionized calcium may be a better predictor of calcium levelsin subjects with CKD than Total and Albumin corrected concentrations calcium estimation.Many factors such as calcium supplementation, $\mathrm{pH}$, serum phosphate and serum albumin levels may lead to underestimation and overestimation of the calcium status in patients with CKD, when only Total calcium or Albumin corrected calcium estimations have been used. These factors need to be evaluated further in a bigger sample size along with clinical correlation.

Conflict of interest: None declared

\section{References}

1. Couser WG, Remuzzi G, Mendis S, Tonelli M. The contribution of chronic kidney disease to the global burden of major noncommunicable diseases. Kidney international. 2011 Dec 2;80(12):1258-70.

2. Singh AK, Farag YM, Mittal BV, Subramanian KK, Reddy SR, Acharya VN, Almeida AF, Channakeshavamurthy A, Ballal HS, Gaccione P, Issacs R. Epidemiology and risk factors of chronic kidney disease in India-results from the SEEK (Screening and Early Evaluation of Kidney Disease) study. BMC nephrology. 2013 May 28;14(1):114.

3. Noordzij M, Korevaar JC, Boeschoten EW, Dekker FW, Bos WJ, Krediet RT, kidney disease outcomes quality initiative (K/DOQI) guideline for bone metabolism and disease in CKD: association with mortality in dialysis patients. American journal of kidney diseases. $2005 \mathrm{Nov}$ 30;46(5):925-32.

4. Toribara TY, Terepka AR, Dewey PA. The ultrafiltrable calcium of human serum;I:ultrafiltration methods and normal values. J Clin Invest 1957;36:738-40.

5. Loken HF, Havel RJ, Gordan GS, Whittington SL. Ultracentrifugal analysis of protein bound and free calcium in human serum. J Bio Chem 1960;235:3654-7.

6. Kidney Disease Outcomes Quality Initiative. Kidney disease outcomes quality initiative (K/DOQI) clinical practice guidelines for chronic kidney disease: evaluation, classification, and stratification. Am J Kidney Dis 2002;39(2 Suppl 1):S1-266.

7. Uhlig K, Berns JS, Kestenbaum B, Kumar R, Leonard MB, Martin KJ, Sprague SM, Goldfarb S. KDOQI US commentary on the 2009 KDIGO clinical practice guideline for the diagnosis, evaluation, and treatment of CKD-mineral and bone disorder (CKD-MBD). American Journal of Kidney Diseases. 2010 May 31;55(5):773-99.

8. Sacré A, Barthélémy P, Korenbaum C, Burgy M, Wolter P, Dumez H, Lerut E, Loyson T, Joniau S, Oyen R, Debruyne PR. Prognostic factors in second-line targeted therapy for metastatic clear-cell renal cell carcinoma after progression on an anti-vascular endothelial growth factor receptor tyrosine kinase inhibitor. ActaOncologica. 2016 Mar 3;55(3):329-40.

9. Clase CM, Norman GL, Beecroft ML, Churchill DN. Albumin-corrected calcium and ionized calcium in stable haemodialysis patients. Nephrology Dialysis Transplantation. 2000 Nov 1;15(11):1841-6.

10. Ammirati AL, Dalboni MA, Cendoroglo M, Draibe SA, Santos RD, Miname M, Canziani ME. The progression and impact of vascular calcification in peritoneal dialysis patients. Peritoneal Dialysis International. 2007 May 1;27(3):340-6.
11. Gucalp R, Ritch P, Wiernik PH, Sarma PR, Keller A, Richman SP, Tauer K, Neidhart J, Mallette LE, Siegel R. Comparative study of pamidronate disodium and etidronate disodium in the treatment of cancer-related hypercalcemia. Journal of clinical oncology. 1992 Jan;10(1):134-42.

12. Hecking M, Kainz A, Bielesz B, Plischke M, Beilhack G, Hoerl WH, Sunder-Plassmann G, Bieglmayer C, Benchetrit S, Green J, Bernheim J. Mineral and bone disease-Ckd 5d. Nephrology Dialysis Transplantation. 2012 May; 1(27): 492-510. 